\title{
COMPARATIVE ANALYSIS OF CURRICULA OF THREE COUNTRIES: PAKISTAN, ROMANIA, AND MALAYSIA
}

\section{Sadia Suleman Khan}

Assistant Professor, Department of Education, SBKWU, Quetta, Balochistan,

Pakistan

Email: ssuleman_khan@yahoo.com

\section{Gulab Khan}

PhD in Curriculum \& Instruction, University of North Texas,

USA

\author{
Aliya Ayub \\ Associate Professor, Department of Education \\ SBKWU, Quetta, Balochistan, \\ Pakistan
}

\begin{abstract}
This analytical paper presents findings from comparison of current Pakistani curriculum with the curricula of Malaysia and Romania and their implications for future curricular practices in Pakistan. The curricula of the three countries have been viewed from the perspectives of 10 guiding curricular components scope, sequence, continuity, articulation, balance, self-sufficiency, significance, interest, utility, and feasibility; in addition to other parameters such as curriculum development and change processes. The implications for future curriculum practices include: the inclusion of local cultural values, wisdom, stories, songs, art, music, peace education, literature, in the curriculum; a balance between art education and science education; matching the expectations of the curriculum and the society with the existing realities and available resources; survey of the needs of the society, the social and cultural realities across the province, and so on.
\end{abstract}

\section{KEYWORDS}

Curriculum design, Curricular components, Curriculum processes, Pakistan, Romania, Malaysia, Comparative Analysis 


\section{INTRODUCTION}

Ornstein \& Hunkins (1998) convincingly highlight the influence of curriculum in the following words: Whether we consider curriculum narrowly as a listing of subjects to be taught in schools or broadly as experiences that individuals require for full and authentic participation in society, there is no denying that curriculum affects us all, both those within the field, the educators and curricularists of various stripes, and those in the general society.

Reconceptualizes postulate that the purpose of curriculum is emancipation. Discussing conceptualists, Ornstein \& Hunkins (1998) state, "conceptualists and postmodernists are interested in the interaction of curricula with political, economic, social, cultural, and even artistic forces". Consequently, curriculum always remains under the influence of societal forces. Therefore, curriculum needs constant research and analysis. Education systems working in different countries are continuously deliberating on improving curricular quality. Similarly, curriculum theorists critically analyze the substitute for Tyler rationale that could ensure conducive learning opportunities to learners and make schools better places for personality growth.

Tylerian rationale is still used as a structure and frame for curriculum. However, the model has been improved in many ways in the form of pedagogical strategies, supporting material, in addition to inclusion of diagnosis of needs. Certain models (Taba, 1962; Kelly, 2004) brought changes in Tylerian model to improve curricular practices. Some curriculum scholars of the reconceptualist camp (Doll, 1993; Henderson, 2015) offered alternative to Tyler rationale. Nevertheless, the Tyler rational continues to be the dominant driving force of curriculum development across the globe.

The logic of reconceptualists and postmodernist (Pinar, 1975; Grumet, 1981; Slattery, 1995) regarding curriculum is highly convincing but more philosophical and subjective. The alternatives to Tyler model have never been objective in form that encompasses learning experiences, content, activities providing opportunities to children for their growth (Ornstein \& Hunkins, 1998; Henson, 2006; Glatthorn et al, 2006). English (2010), Ornstein \& Hunkins (1998) seem to opt for the middle course. They suggest the confluence of the curricular theorists to discuss curriculum from political, social, cultural, and economic angles and at the same time provide a systematic document that could 
guide the teaching learning processes taking place at school and classroom levels.

This analytical paper examines the curricula and related constructs of two countries, Malaysia and Romania and compare them with current Pakistani curriculum in relation to the underlying curricular components impacting the design, aims and objectives, selection criteria for content, and so on. "Curriculum design refers to the way we conceptualize the curriculum and arrange its major components (subject matter content, instructional methods and material, learner experiences or activities) to provide direction and guidance as we develop the curriculum" (Ornstein \& Hunkins, 1998, p.19).

\section{Rationale for the selection of the countries}

The purpose of the analysis was to identify and understand the progress of the education systems of the selected nations based on improvements in their curricula. One of the major criteria was to choose countries whose past have similarities with Pakistani history. Romania as a nation went through the same vicissitude of the history as did Pakistan. The country witnessed ideological influence of the two world powers - socialism and communism. History of the country shows that it remained part of socialist block under the former USSR. The education system of the country went through certain formative and transformative phases. Now the education system is one of the few countries performing very well on international competition scales. Furthermore, the country is making headway in economic growth.

The reason to select Malaysia is that it is the fastest growing country on economic grounds among all the Muslim majority nations. Also, its education system went through a drastic policy shift in the 1990s. Due to the policy shift in education system, curriculum also went through major changes. As a Muslim state, where people urge the Islamic values to be in vogue, Pakistan has the advantage to learn from the positive aspects of Malaysian curriculum. Malaysia also emphasizes Islamic education but, in a way, that it promotes the overall wellbeing of the nation. How Malaysia was successful in establishing Malay language as the medium of instruction alongside English is an interesting phenomenon.

\section{Conceptual framework}

Henson (2006) and Ornstein \& Hunkins (1998) have discussed factors that 
should be kept into consideration while developing curriculum. Some of these factors are: scope, balance, continuity, articulation, balance (Henson, 2006, p. 174-175) and self-sufficiency, significance, interest, feasibility, utility and learnability (Ornstein \& Hunkins, 1998). In this work, the curricula of the three countries will be analyzed and compared considering these components.

These components were selected to have an explicit understanding of the curricular practices of these three countries and what might be some implications to guide future curriculum exercise in Baluchistan. The selection of these components is mainly motivated by the curricular requirement of Baluchistan province in relation to the existing realities. Following is the short definition and meaning of each factor in the sphere of curriculum.

\section{Scope}

Curriculum scope, a horizontal dimension, refers to the breadth of the curriculum at any level or at any given time. For example, the breadth of eighthgrade science refers to the variety of science topics covered during the eighth grade.

\section{Sequence}

Curriculum sequence, being a vertical dimension, is concerned with the order of topics over time. For example, in biology, students might study the cell and then tissue, organs, organ, and system.

\section{Continuity}

Continuity refers to the smoothness or the absence of disruptions in the curriculum over time. A curriculum that has good sequence but also has disruptions lacks continuity.

\section{Articulation}

Articulation refers to the smooth flow of the curriculum in both dimensions, vertical and horizontal.

\section{Balance}

Balance refers to the ratio of representation between arts and science subjects or between college prep subjects and vocational subjects and so on in the curriculum. (p. 174-175). 


\section{Self-sufficiency}

One of the guiding principles for content selection is to help learners attain selfsufficiency in the most economical manner-economy of teaching efforts and educational resources, economy of students' efforts, and economy of subject matter's extent of generalizability. This criterion has also been supported by humanists, reconceptualize, and radical postmodernists as a means by which learners can actualize their potential and crystalize their identities.

Content is significant when it contributes ideas, concepts, principles and so on to the overall aim of curriculum. Taba (1962) stressed that we should focus both cognitive and affective domain of a learner. A subject matter design will weigh knowledge as a significant thing in the curriculum whereas learner-centered design looks for meaning in the experiences of the pupils and problem-centered design would consider significance in terms of particular social, political, and economic issues.

Ornstein \& Hunkins (1998) pose question to the William Reid idea that content should be selected with an eye to its cultural significance. "Does the content to be leaned or constructed add to the overall culture of the nation or group? This criterion becomes controversial as to how we define curriculum, and can the selected content give sense of culture to students? Closely related to this criterion is that content should be selected that serves local, regional, and national interests. The challenge is to come to a consensus as to what such interest are" (p. 215).

\section{Interest}

This criterion is very important to the propagators of learner-centered approach of

curriculum development. These persons note that knowledge exists in the learner when it is meaningful to his or her life. The criterion of students' interest should be weighed and adjusted to allow for students' maturity, their prior experiences, and educational and social values for their interest, and the way they expect to interact with society.

\section{Utility}

Utility concerns the usefulness of the content. Usefulness is dependent on a person's philosophical view and favored curriculum design. Usefulness to those favoring the subject-matter design is often judged in terms of how the content 
learned will enable students to use that knowledge in job situations and other adult activities. The supporters of learner-centered camp would see if the selected content has the ability to enable and individual to gain an accurate perception of his or her self-identity and to attain meaning in his or her life. Proponents of problem-centered mode would think of content as having utility if it has direct application to ongoing life and to social and political issues.

\section{Feasibility}

Feasibility forces curriculum planners to consider content in light of the time allowed, the resources available, and the expertise of the current staff, the nature of political climate, the existing legislation, and the amount of public monies available. Content of the selection has to be considered within the context of the existing reality (my emphasis), which usually boils down to economics and politics. (Adopted with minor rephrasing from: Henson, 2006, p. 174-175; Ornstein \& Hunkins, 1998, 215-217).

Besides, the study seeks guidance from the report of the international comparative study of school curriculum undertaken by national institute of educational research (NIER) Japan (1998). The study compares various features of the school curricula of 19 countries from around the world. The following table presents the analysis of curricular components of the three countries in relation to the selected curricular components.

\section{RESEARCH QUESTIONS}

1. In what ways are Malaysian and Romanian curricula different or similar to Pakistani curriculum?

2. What is the curriculum making and change process in the three selected countries?

3. What are the implications of the curricular practices of the three countries?

\section{RESEARCH METHODOLOGY}

There has been meagre research on comparative analysis of curriculum among countries. UNESCO (2018) offered a comparative study. comparing curriculum frameworks of five countries - Brazil, Cambodia, Finland, Kenya, and Peru. This study is prototypical in that it underscores major curriculum components for comparison.

The current study, on similar patterns, provides a picture where the curricula of 
the three countries - Pakistan, Romania, and Malaysia differ or converge. Curriculum components are selected on the basis that they truly represent the overall design of the curriculum. Additionally, curriculum construction and change processes in the three selected countries are analyzed and compared.

\section{DATA ANALYSIS}

\section{Table 1}

Showing analysis of the curricular components of the three countries

\begin{tabular}{|c|c|c|c|}
\hline & Pakistan & Romania & Malaysia \\
\hline Scope & $\begin{array}{l}\text { Pakistani } \\
\text { curriculum over- } \\
\text { emphasizes } \\
\text { Science, } \\
\text { Mathematics, and } \\
\text { English language. } \\
\text { Islamic education } \\
\text { also has been } \\
\text { given } \\
\text { overwhelming } \\
\text { weightage. The } \\
\text { curriculum has } \\
\text { been criticized } \\
\text { for ideological } \\
\text { integration in the } \\
\text { non-theological } \\
\text { subject curricula. } \\
\text { The curriculum is } \\
\text { overly abundant } \\
\text { with, skills, } \\
\text { knowledge, and } \\
\text { tasks. }\end{array}$ & $\begin{array}{l}\text { Science and } \\
\text { languages } \\
\text { (particularly } \\
\text { Romanian } \\
\text { language) occupy } \\
\text { prominent breadth } \\
\text { and depth. In } \\
\text { comparison to } \\
\text { other two } \\
\text { curricula, the } \\
\text { Romanian } \\
\text { curriculum seems } \\
\text { to have done } \\
\text { justice to the scope } \\
\text { of topics of } \\
\text { various subject } \\
\text { areas. }\end{array}$ & $\begin{array}{l}\text { In Malaysia } \\
\text { curriculum, Malay } \\
\text { language is } \\
\text { incomparably } \\
\text { dominant. For } \\
\text { example, time } \\
\text { allocation at } \\
\text { primary level for } \\
\text { Malay language is } \\
450 \text { minutes } \\
\text { whereas for } \\
\text { English language it } \\
\text { is } 240 \text { and for } \\
\text { Mathematics } 210 \text {. } \\
\text { Burdon of } \\
\text { vocational } \\
\text { subjects-most } \\
\text { areas of } \\
\text { engineering are } \\
\text { taught at upper } \\
\text { secondary level. }\end{array}$ \\
\hline Sequence & $\begin{array}{l}\text { Unlike other two } \\
\text { curricula, } \\
\text { Pakistani } \\
\text { curriculum }\end{array}$ & $\begin{array}{l}\text { The sequence of } \\
\text { Romanian } \\
\text { curriculum bases } \\
\text { on the philosophy }\end{array}$ & $\begin{array}{l}\text { Sequence, in } \\
\text { Malaysian } \\
\text { curriculum, is } \\
\text { being displayed in }\end{array}$ \\
\hline
\end{tabular}




\begin{tabular}{|c|c|c|c|}
\hline & $\begin{array}{l}\text { focuses on the } \\
\text { importance of the } \\
\text { topics and } \\
\text { curricular areas. }\end{array}$ & $\begin{array}{l}\text { of easy to difficult, } \\
\text { known to } \\
\text { unknown, and } \\
\text { concrete to } \\
\text { abstract. There is a } \\
\text { sequence in the } \\
\text { stages of education } \\
\text { according to the } \\
\text { psychological and } \\
\text { societal needs of } \\
\text { the children. }\end{array}$ & $\begin{array}{l}\text { the application of } \\
\text { the integrated } \\
\text { model. Integration } \\
\text { of skills in a } \\
\text { subject - language } \\
\text { teaching, oral } \\
\text { skills, aural skills, } \\
\text { reading and } \\
\text { writing are } \\
\text { incorporated in a } \\
\text { lesson, integration } \\
\text { of old experiences } \\
\text { and newly } \\
\text { acquired } \\
\text { experiences. }\end{array}$ \\
\hline Continuity & $\begin{array}{l}\text { The current } \\
\text { Pakistani } \\
\text { curriculum } \\
\text { claims a } \\
\text { smoothness and } \\
\text { continuity in the } \\
\text { curriculum } \\
\text { regarding mental } \\
\text { age of the learner } \\
\text { and flow of the } \\
\text { learning material. } \\
\text { However, the } \\
\text { textbooks and } \\
\text { other supporting } \\
\text { material don't } \\
\text { support the } \\
\text { propagation at } \\
\text { length. The } \\
\text { continuity issues } \\
\text { may be } \\
\text { minimized with }\end{array}$ & $\begin{array}{l}\text { Romanian } \\
\text { curriculum ensures } \\
\text { continuity through, } \\
\text { transfer of didactic } \\
\text { methods; } \\
\text { establishing } \\
\text { explicit } \\
\text { connections at the } \\
\text { curriculum level; } \\
\text { and a better } \\
\text { correlation } \\
\text { between the } \\
\text { mental age and the } \\
\text { curriculum } \\
\text { structure. }\end{array}$ & $\begin{array}{l}\text { Malaysian } \\
\text { curriculum ensures } \\
\text { the level wise } \\
\text { continuity and } \\
\text { vows to work on } \\
\text { child being } \\
\text { holistic. The } \\
\text { curriculum } \\
\text { indicates that } \\
\text { Education in } \\
\text { Malaysia is an } \\
\text { ongoing effort } \\
\text { towards further } \\
\text { developing the } \\
\text { potentials of } \\
\text { individuals in a } \\
\text { holistic and } \\
\text { integrated manner } \\
\text { in order to produce } \\
\text { individuals who } \\
\text { are intellectually, } \\
\text { spiritually, }\end{array}$ \\
\hline
\end{tabular}




\begin{tabular}{|c|c|c|c|}
\hline & $\begin{array}{l}\text { the experience } \\
\text { and practice. }\end{array}$ & & $\begin{array}{l}\text { emotionally and } \\
\text { physically } \\
\text { balanced and } \\
\text { harmonious. }\end{array}$ \\
\hline Articulation & $\begin{array}{l}\text { Though the } \\
\text { current Pakistani } \\
\text { curriculum is a } \\
\text { better version } \\
\text { after many years } \\
\text { of reform, it still } \\
\text { needs a lot of } \\
\text { work to enable it } \\
\text { function } \\
\text { reasonably. The } \\
\text { concepts and } \\
\text { ideas fluctuate in } \\
\text { terms of vertical } \\
\text { articulation. For } \\
\text { example, social } \\
\text { studies is } \\
\text { converted to } \\
\text { Pakistan studies } \\
\text { at } 9^{\text {th }} \text { grade. It } \\
\text { means that up to } \\
\text { grade eight } \\
\text { children study } \\
\text { pluralistically } \\
\text { about other } \\
\text { societies, but they } \\
\text { are channeled } \\
\text { back to Pakistan } \\
\text { studies only. }\end{array}$ & $\begin{array}{l}\text { There is a feeling } \\
\text { of vertical flow in } \\
\text { the Romanian } \\
\text { curriculum. With } \\
\text { the promise of } \\
\text { constructivism, the } \\
\text { subject of a grade } \\
\text { build on the } \\
\text { previous } \\
\text { knowledge and } \\
\text { smoothly moves } \\
\text { forward. }\end{array}$ & $\begin{array}{l}\text { In Malaysian } \\
\text { curriculum, } \\
\text { articulation can be } \\
\text { viewed at the } \\
\text { proceeding stages } \\
\text { and level. For } \\
\text { example, at } \\
\text { elementary level, } \\
\text { the list of subjects } \\
\text { is short. The list } \\
\text { expands in } \\
\text { quantity and scope } \\
\text { at secondary and } \\
\text { upper secondary } \\
\text { level. It seems as if } \\
\text { the curriculum is } \\
\text { taking the students } \\
\text { to upper grades in } \\
\text { smooth flow. }\end{array}$ \\
\hline Balance & $\begin{array}{l}\text { Pakistani } \\
\text { curriculum } \\
\text { overemphasizes } \\
\text { science, } \\
\text { Mathematics, and }\end{array}$ & $\begin{array}{l}\text { Romanian } \\
\text { curriculum is an } \\
\text { excellent } \\
\text { combination of } \\
\text { arts, science, }\end{array}$ & $\begin{array}{l}\text { There are so many } \\
\text { issues of balance } \\
\text { in Malaysian } \\
\text { curriculum. There } \\
\text { is imbalance }\end{array}$ \\
\hline
\end{tabular}




\begin{tabular}{|c|c|c|c|}
\hline & $\begin{array}{l}\text { English. It has } \\
\text { ignored art, } \\
\text { music, literature, } \\
\text { physical } \\
\text { education in } \\
\text { general and at } \\
\text { primary level. In } \\
\text { the list of core } \\
\text { subjects, there is } \\
\text { imbalance } \\
\text { between } \\
\text { humanities and } \\
\text { science. The } \\
\text { curriculum } \\
\text { stresses on } \\
\text { academic } \\
\text { disciplines. }\end{array}$ & $\begin{array}{l}\text { humanities, and } \\
\text { languages. The } \\
\text { seven core } \\
\text { curriculum areas } \\
\text { are as follows, } \\
\text { languages and } \\
\text { communication, } \\
\text { Mathematics and } \\
\text { natural sciences, } \\
\text { Man and society, } \\
\text { Arts, Physical } \\
\text { education and } \\
\text { sports, } \\
\text { technologies, } \\
\text { counseling and } \\
\text { guidance. }\end{array}$ & $\begin{array}{l}\text { between arts and } \\
\text { science } \\
\text { curriculum. } \\
\text { Science is } \\
\text { dominant except } \\
\text { for languages. } \\
\text { Science subjects } \\
\text { are part of } \\
\text { curriculum and } \\
\text { there is a huge list } \\
\text { of vocational } \\
\text { subjects such as } \\
\text { that of } \\
\text { engineering. Art } \\
\text { education, music } \\
\text { education, health } \\
\text { and physical } \\
\text { education are } \\
\text { included in the } \\
\text { elective subjects } \\
\text { which have no } \\
\text { required credits to } \\
\text { qualify for the next } \\
\text { grade. }\end{array}$ \\
\hline $\begin{array}{c}\text { Self- } \\
\text { sufficiency }\end{array}$ & $\begin{array}{l}\text { Pakistan's } \\
\text { national } \\
\text { curriculum is a } \\
\text { narrative of } \\
\text { unrealistic } \\
\text { expectations of } \\
\text { policy actors and } \\
\text { law makers. } \\
\text { There is a huge } \\
\text { difference } \\
\text { between the } \\
\text { expectations of } \\
\text { curriculum and }\end{array}$ & $\begin{array}{l}\text { Romanian } \\
\text { curriculum } \\
\text { matches the } \\
\text { ground realities for } \\
\text { the most extent. } \\
\text { Romanian } \\
\text { curriculum can } \\
\text { achieve self- } \\
\text { sufficiency due to } \\
\text { the reasonable } \\
\text { scope and balance. } \\
\text { There is some } \\
\text { flexibility in time }\end{array}$ & $\begin{array}{l}\text { Malaysia's } \\
\text { curriculum is } \\
\text { partly self- } \\
\text { sufficient. The } \\
\text { country has } \\
\text { enough material } \\
\text { resources for the } \\
\text { education system } \\
\text { whereas they are } \\
\text { striving for } \\
\text { improving human } \\
\text { resources to be } \\
\text { self-sufficient. }\end{array}$ \\
\hline
\end{tabular}




\begin{tabular}{|c|c|c|c|}
\hline & $\begin{array}{l}\text { available } \\
\text { resources }\end{array}$ & $\begin{array}{l}\text { allocation for } \\
\text { various subjects. }\end{array}$ & $\begin{array}{l}\text { Teachers are on } \\
\text { the way to } \\
\text { translate modern } \\
\text { pedagogical } \\
\text { strategies to the } \\
\text { classroom } \\
\text { practices. }\end{array}$ \\
\hline Significance & $\begin{array}{l}\text { Pakistan's latest } \\
\text { curriculum is } \\
\text { theoretically } \\
\text { learner-centered, } \\
\text { but it doesn't } \\
\text { provide objective } \\
\text { implementation } \\
\text { strategies } \\
\text { according to the } \\
\text { local culture and } \\
\text { context. It is } \\
\text { outcome-based } \\
\text { (Boschee \& } \\
\text { Baron, 1993) that } \\
\text { can help children } \\
\text { to understand and } \\
\text { conceptualize } \\
\text { ideas and } \\
\text { meaning, } \\
\text { provided all the } \\
\text { factors } \\
\text { coordinate. }\end{array}$ & $\begin{array}{l}\text { Romania claims to } \\
\text { have adapted the } \\
\text { curriculum, as a } \\
\text { whole, to the } \\
\text { national socio- } \\
\text { cultural context. } \\
\text { Furthermore, the } \\
\text { objectivity of } \\
\text { curriculum; the } \\
\text { nature of being } \\
\text { outcome-based } \\
\text { and being learner- } \\
\text { centered make the } \\
\text { curriculum } \\
\text { significant. }\end{array}$ & $\begin{array}{l}\text { Malaysia's } \\
\text { sensitivity to the } \\
\text { national } \\
\text { consciousness and } \\
\text { the promotion of } \\
\text { Malay language as } \\
\text { a national cultural } \\
\text { symbol, makes the } \\
\text { curriculum } \\
\text { significant. } \\
\text { However, the } \\
\text { curriculum is } \\
\text { content-based } \\
\text { (Kelly, 2004) } \\
\text { which again poses } \\
\text { questions to its } \\
\text { significance. }\end{array}$ \\
\hline Interest & $\begin{array}{l}\text { The ideological } \\
\text { bases of } \\
\text { curriculum in } \\
\text { Pakistan leaves } \\
\text { little room for the } \\
\text { interest of the } \\
\text { learners. The } \\
\text { curriculum }\end{array}$ & $\begin{array}{l}\text { Romanian } \\
\text { curriculum } \\
\text { promises that it } \\
\text { provides } \\
\text { opportunities to } \\
\text { children to } \\
\text { discover their own } \\
\text { interest, }\end{array}$ & $\begin{array}{l}\text { The national } \\
\text { curriculum is an } \\
\text { integrated } \\
\text { curriculum } \\
\text { emphasizing on } \\
\text { the holistic } \\
\text { development of the } \\
\text { students. It }\end{array}$ \\
\hline
\end{tabular}




\begin{tabular}{|c|c|c|c|}
\hline & $\begin{array}{l}\text { claims that it } \\
\text { promotes critical } \\
\text { and creative } \\
\text { thinking of the } \\
\text { learners which is } \\
\text { hard to be } \\
\text { executed in a } \\
\text { conservative } \\
\text { society. Besides, } \\
\text { developing } \\
\text { nations usually } \\
\text { focus on national } \\
\text { and societal } \\
\text { needs. }\end{array}$ & $\begin{array}{l}\text { aspirations, and } \\
\text { values in order to } \\
\text { build a positive } \\
\text { self-image. The } \\
\text { curriculum urges } \\
\text { teachers to take } \\
\text { care of the } \\
\text { students' interest } \\
\text { and discover their } \\
\text { aptitudes. }\end{array}$ & $\begin{array}{l}\text { provides } \\
\text { opportunities for } \\
\text { the students to } \\
\text { develop basic } \\
\text { skills, knowledge, } \\
\text { values, attitudes, } \\
\text { interests and } \\
\text { talents. However, } \\
\text { like Pakistani, the } \\
\text { goals of Malaysian } \\
\text { curriculum focus } \\
\text { the national ideals, } \\
\text { unity, ideology } \\
\text { and the needs of } \\
\text { the society. }\end{array}$ \\
\hline Feasibility & $\begin{array}{l}\text { Pakistani } \\
\text { curriculum is } \\
\text { based on huge } \\
\text { array of } \\
\text { unrealistic } \\
\text { expectations } \\
\text { because of the } \\
\text { issues in } \\
\text { feasibility which } \\
\text { are as follows: } \\
\text { lack of resources, } \\
\text { unavailability of } \\
\text { expert staff, } \\
\text { unfavorable } \\
\text { political and } \\
\text { economic } \\
\text { climate; lower } \\
\text { budget allocated } \\
\text { for education, } \\
\text { and the existing } \\
\text { legislation. In } \\
\text { short, most part }\end{array}$ & $\begin{array}{l}\text { Romania has } \\
\text { comparatively } \\
\text { more resourceful } \\
\text { due to its } \\
\text { economic growth } \\
\text { and higher } \\
\text { allocation of funds } \\
\text { for educational } \\
\text { activities. } \\
\text { Additionally, } \\
\text { Romania's } \\
\text { political climate is } \\
\text { also stable. There } \\
\text { is availability of } \\
\text { expert staff. Since } \\
\text { the curriculum is } \\
\text { close to reality, the } \\
\text { chances of } \\
\text { feasibility are } \\
\text { maximum. }\end{array}$ & $\begin{array}{l}\text { Malaysia's } \\
\text { economic growth } \\
\text { and political } \\
\text { stability proves } \\
\text { that the continual } \\
\text { reform in } \\
\text { curriculum gives } \\
\text { better results. } \\
\text { Malaysia allocates } \\
\text { enough funds for } \\
\text { educational } \\
\text { activities. }\end{array}$ \\
\hline
\end{tabular}


Pakistan Journal of Educational Research, Vol 2, Issue 2 (2019) Comparative analysis. .

\begin{tabular}{|c|c|c|c|}
\hline & $\begin{array}{l}\text { of the curriculum } \\
\text { is against the } \\
\text { existing reality. }\end{array}$ & & \\
\hline Utility & $\begin{array}{l}\text { Pakistani } \\
\text { curriculum in in } \\
\text { transition from } \\
\text { subject-centered } \\
\text { to learner- } \\
\text { centered } \\
\text { approach. } \\
\text { Because of the } \\
\text { ideological and } \\
\text { religious } \\
\text { dominance in the } \\
\text { curriculum, there } \\
\text { is little space for } \\
\text { sociocultural } \\
\text { identities. }\end{array}$ & $\begin{array}{l}\text { Romania's } \\
\text { curriculum is } \\
\text { learner-centered } \\
\text { and addresses the } \\
\text { major areas of } \\
\text { human life and } \\
\text { activity. It has an } \\
\text { approach of } \\
\text { balance between } \\
\text { economic growth } \\
\text { of the individual } \\
\text { and the nation, and } \\
\text { human aspects of } \\
\text { societal life. On } \\
\text { one hand the } \\
\text { curriculum } \\
\text { promotes } \\
\text { technological } \\
\text { knowledge, on the } \\
\text { other, gives equal } \\
\text { weightage to the } \\
\text { subject areas of } \\
\text { man and society. }\end{array}$ & $\begin{array}{l}\text { Malaysian } \\
\text { curriculum is } \\
\text { subject specific } \\
\text { and content-based. } \\
\text { One of the major } \\
\text { goals is to produce } \\
\text { trained human } \\
\text { resource for the } \\
\text { growing industry. } \\
\text { Therefore, there is } \\
\text { a lengthy list of } \\
\text { vocational and } \\
\text { technological } \\
\text { subjects - } \\
\text { Principles of } \\
\text { Accounts, Basic } \\
\text { Economics, } \\
\text { Commerce, } \\
\text { Agriculture Science, } \\
\text { Home Economics, } \\
\text { Additional } \\
\text { Mathematics, } \\
\text { Mechanical } \\
\text { Engineering Studies, } \\
\text { Civil Engineering } \\
\text { Studies, Electrical } \\
\text { and Electronic } \\
\text { Engineering Studies, } \\
\text { Engineering } \\
\text { Drawing, } \\
\text { Engineering } \\
\text { Technology, and } \\
\text { invention. }\end{array}$ \\
\hline
\end{tabular}


Figure 1: An analytical map of the analysis showing similarities and differences in curriculum design of the three countries.
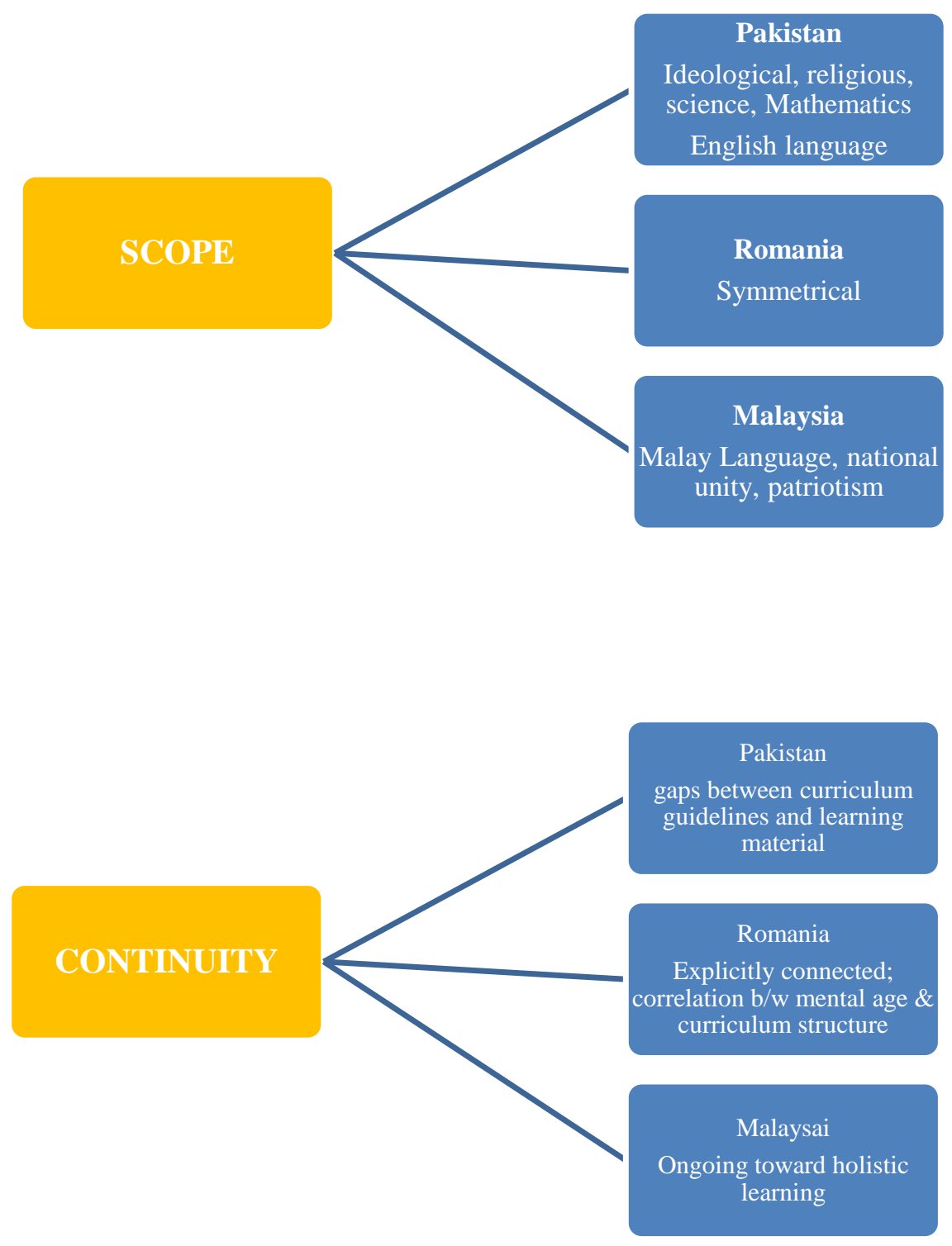

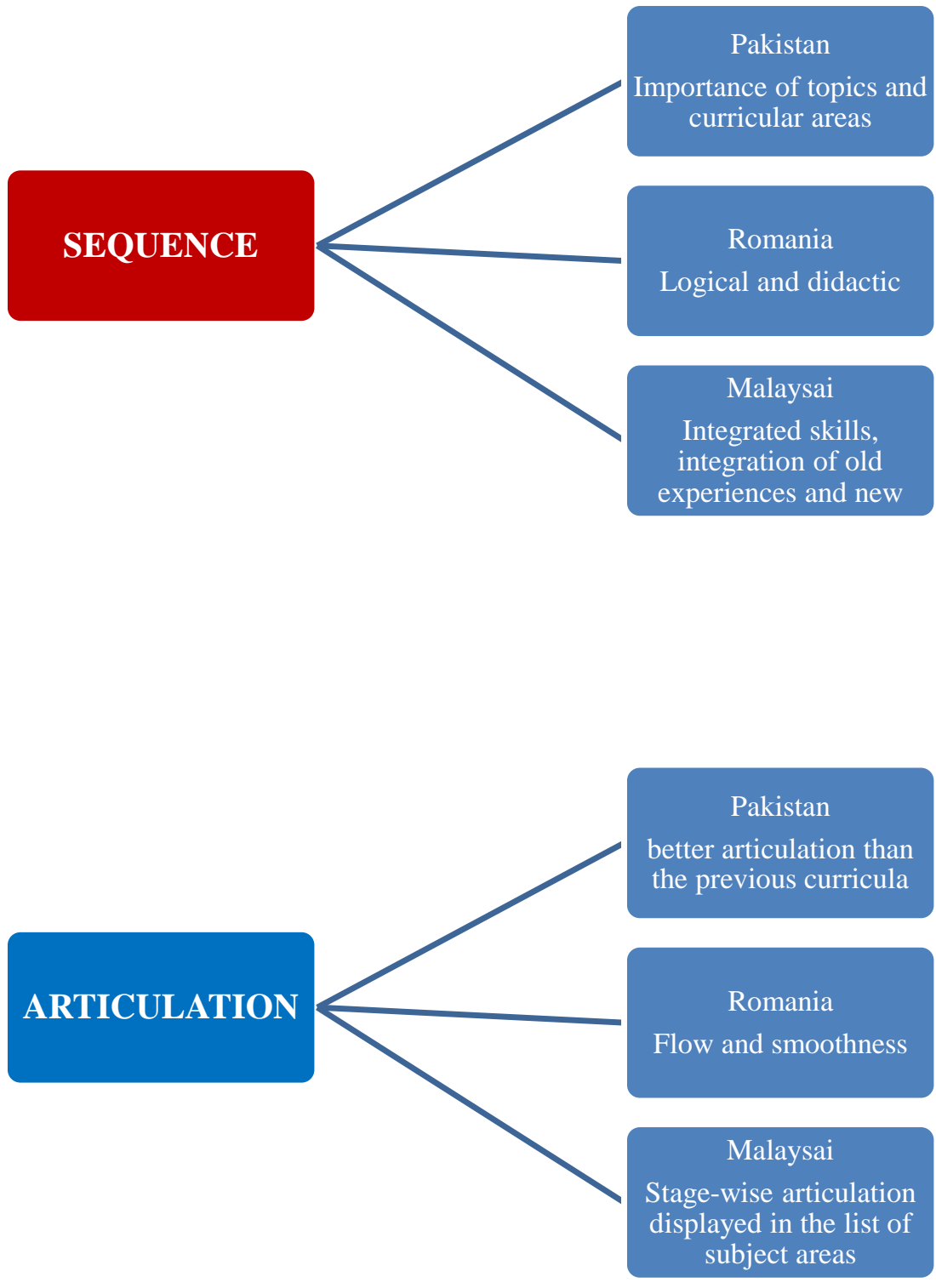

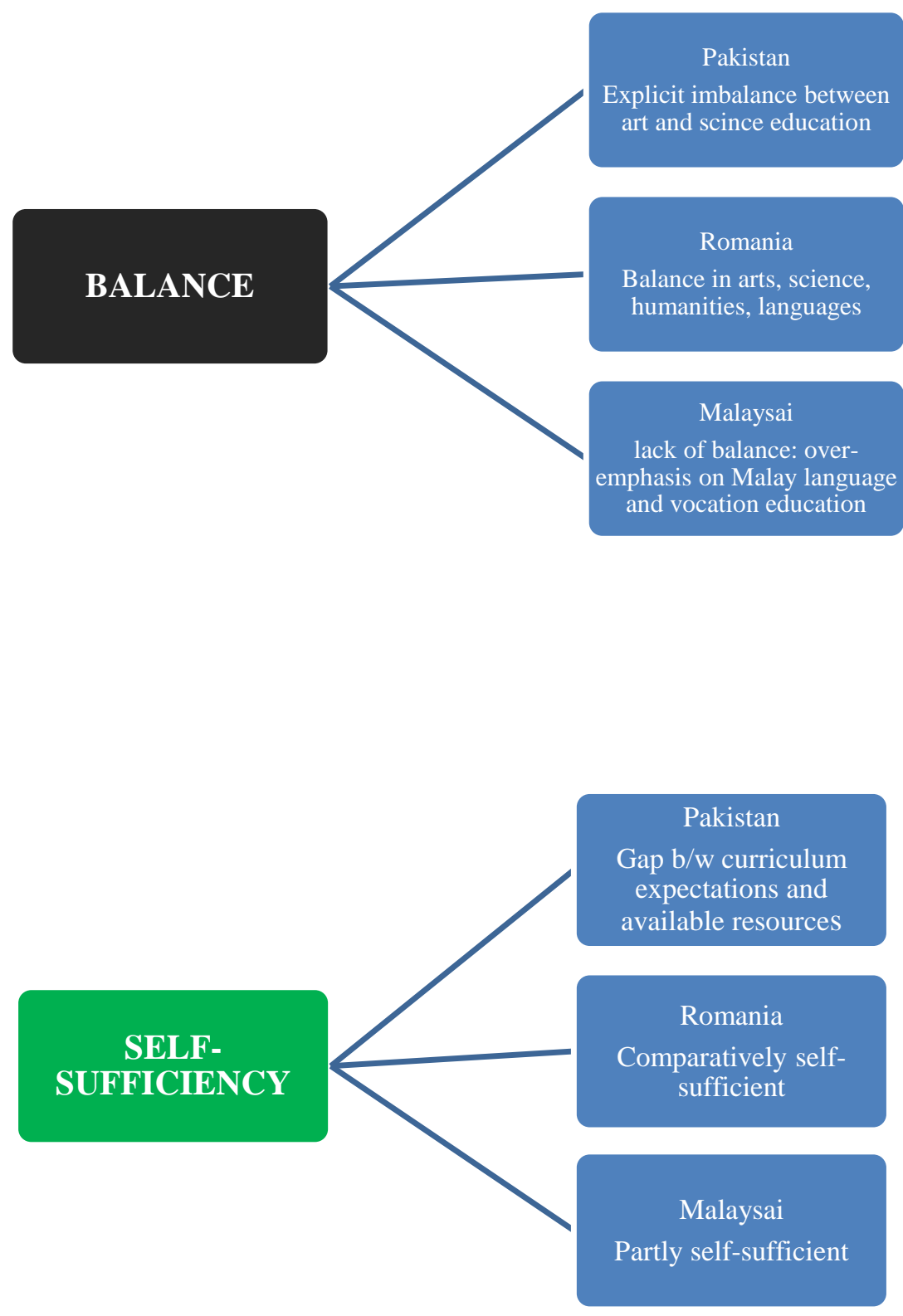

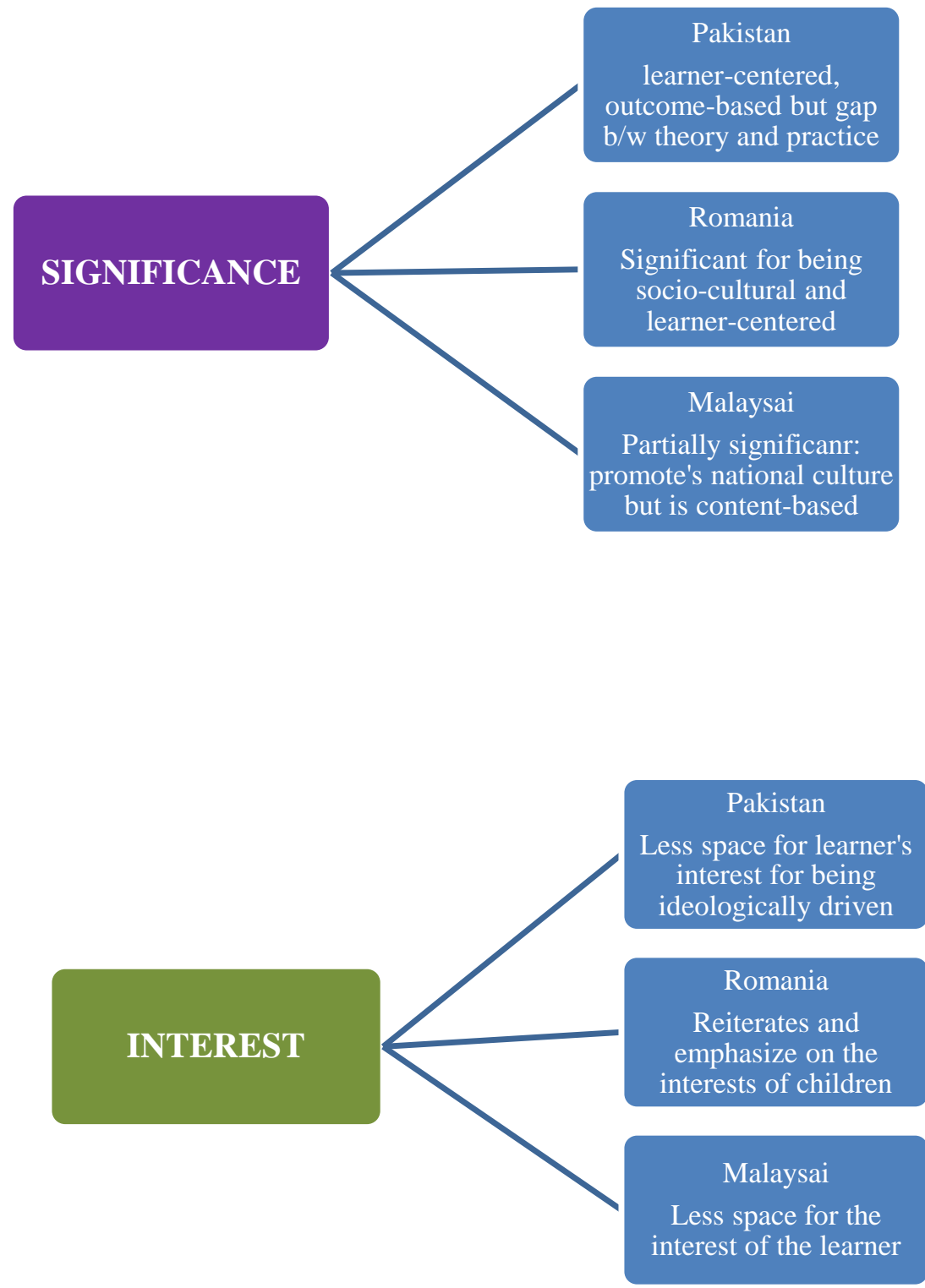

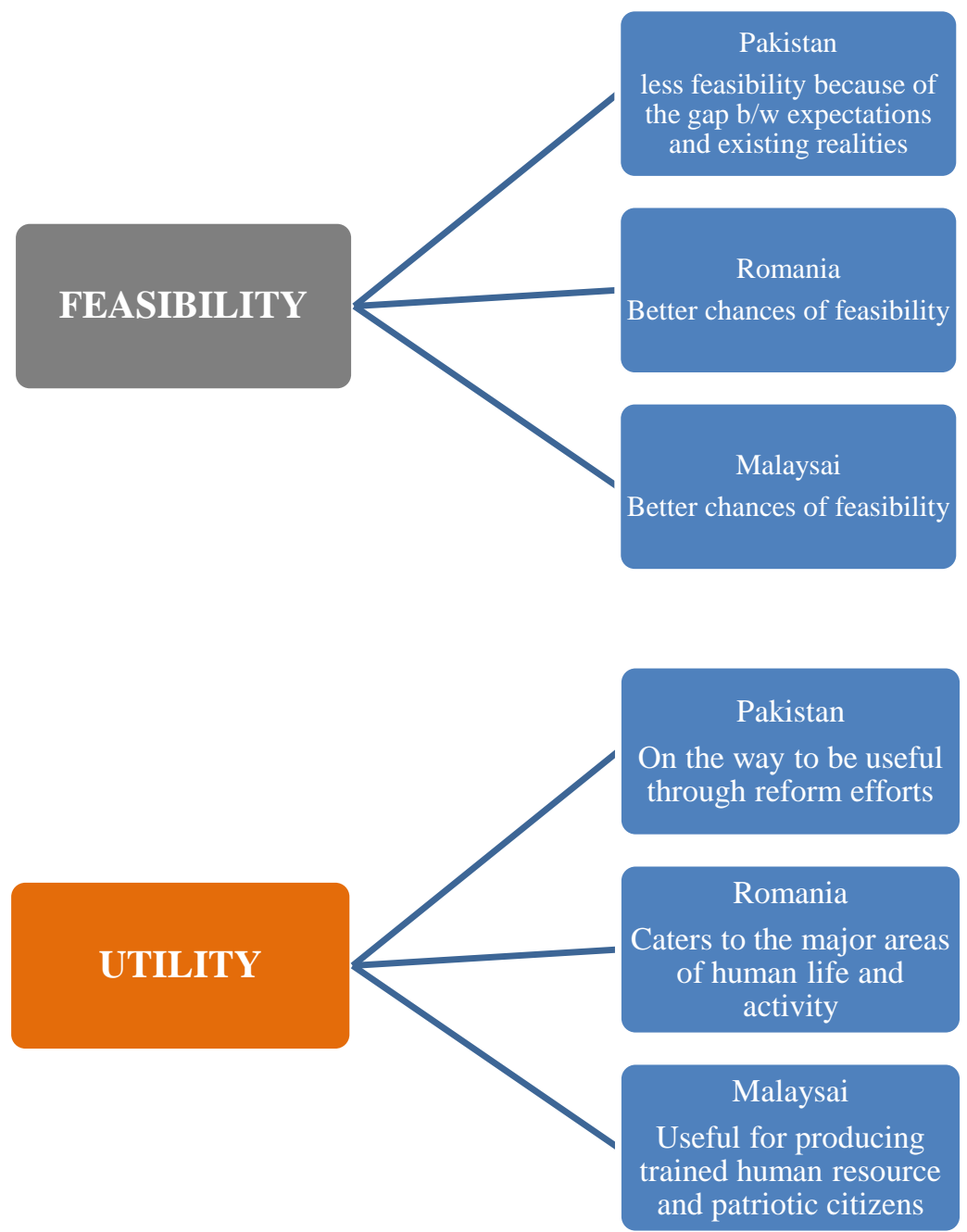

Following are some of the other parameters and characteristics of the curricula of the three countries to understand how curriculum works in the three countries.

\section{Educational goals/aims}

All three countries have explicitly expressed their goals and aims for the education systems of their respective countries. These goals and aims 
encompass all the following areas but not limited to them: child's emotional, intellectual, spiritual, and physical growth; and child's critical thinking and problem-solving skills. The curricula of all the three countries seem committed to better social order within the country and better relations to the outside world. The curricula of Malaysia and Pakistan seem to be overwhelmed with religious goals and objectives whereas Romania's curriculum seems secular in nature.

\section{Curriculum change}

The curricula of all three countries have been going through changes at different level, driven by proposals for reform with the changing time and needs of the society. The most prominent changes are the introduction of new subjects alongside changes in models and approaches. Some of the new subjects introduced in the latest curricula of the three countries are environmental education and ICT. The curricula are committed to improvement in the future. Countries like Pakistan are looking forward to including subjects such as human rights, education for participant in the international society, tolerance and peace education, cultural values and cultural diversity. The curriculum of Malaysia has become more centralized whereas Pakistan has devolved the power of education to provinces. Romania allows local content from $20 \%$ to $25 \%$ whereas $75 \%$ to $80 \%$ share in curriculum is centralized. All the three countries pay due heed to the best practices and research around the world. They are planning to implement modern pedagogical strategies of teaching learning - mastery learning, cooperative learning, and activity-based learning.

\section{Initiation of curriculum development}

It is very necessary to understand the worth of curriculum by looking at the agencies who are initiating the development process and agencies which are consulted for this task. Usually most of the stakeholders are involved in the initiation of the curriculum development process. The following table shows the initiation and consultation of curriculum development.

\section{Table 2}

Initiation of curriculum development

\begin{tabular}{lll}
\hline Country & $\begin{array}{c}\text { Agency initiating } \\
\text { curriculum development }\end{array}$ & \multicolumn{1}{c}{ Agencies consulted } \\
\hline Romania & Education department & $\begin{array}{l}\text { Curriculum } \\
\text { evaluation specialist, teachers, } \\
\text { students, parents }\end{array}$ \\
\hline
\end{tabular}




\begin{tabular}{lll} 
Pakistan & $\begin{array}{l}\text { Curriculum wing, ministry of } \\
\text { federal education }\end{array}$ & $\begin{array}{l}\text { Education specialists, } \\
\text { curriculum experts, education } \\
\text { administrators }\end{array}$ \\
Malaysia & $\begin{array}{l}\text { Curriculum development } \\
\text { center (CDC) }\end{array}$ & $\begin{array}{l}\text { Professional bodies, Education } \\
\text { experts/moderators }\end{array}$ \\
\hline
\end{tabular}

\section{Curriculum approaches to promote unity and cultural diversity}

It is a general observation about a large-scale curriculum (national or provincial) that it is designed as to promote national unity. Malaysia brought about drastic changes in its curricular practices in 1990. The curriculum highly emphasized promoting national unity through curriculum. To attain this goal, Malaysia introduced the national language Malay as the medium of instruction at all levels, including higher education. The second thing for national unity in Malaysia is the emphasis on Islamic education. To maintain cultural diversity, Malaysia introduced languages of other ethnicities at school level - Chines, Tamil, and others. Pakistan's curriculum also emphasizes Islamic education as an ideological inspiration for national unity. Pakistan's national language couldn't receive such an elevated position as Malay did in Malaysia. As for as future curriculum practices are concerned, Pakistani education system plans to give due weightage to cultural diversity. Cultural diversity is one of the reasons that future curricula will be provincial instead of national. Romania's curriculum is sensitive to socio-cultural factors. The curriculum gives priority to the principle of socio-cultural context.

Table 3

Basic approaches to curriculum design

\begin{tabular}{|c|c|c|c|}
\hline Country & Approach & Model & Process \\
\hline Romania & $\begin{array}{l}\text { Outcome- } \\
\text { based }\end{array}$ & Student-centered & $\begin{array}{l}\text { Needs assessment, setting } \\
\text { objectives, selection of } \\
\text { content, teaching } \\
\text { strategies/activities, } \\
\text { assessment }\end{array}$ \\
\hline Pakistan & $\begin{array}{l}\text { Outcome- } \\
\text { based from } \\
\text { content- } \\
\text { based }\end{array}$ & $\begin{array}{l}\text { Linear student- } \\
\text { centered in } \\
\text { theory and } \\
\text { teacher-centered } \\
\text { in practice }\end{array}$ & $\begin{array}{l}\text { Setting objectives, selection } \\
\text { of content, teaching } \\
\text { strategies/activities, } \\
\text { assessment }\end{array}$ \\
\hline
\end{tabular}


Malaysia Content- Integrated model Needs analysis, research based and and planning, design and skill-based development, trial/limited implementation, dissemination and implementation, supervision and evaluation

\section{Curriculum Implementation}

Curriculum implementation is the biggest challenge to any education system. In the three countries, Pakistan is facing challenging issues in implementing curriculum. It has always been noticed in Pakistan's public education system that policy documents usually seem very attractive upon reading, but only a minimal proportion meets implementation. Some of the general barriers in the way of implementation, as noticed by education experts, are as follows: lack of resources (both human and material), poor infrastructure; resistance to change, highly unrealistic expectations of policymakers.

\section{DISCUSSION}

Pakistani and Malaysian curricula share some commonalities. Both the curricula are ideologically driven and expected to work as vehicles for national unity. Both the countries emphasize the acquisition of religious (Islamic) education. Both the nations use national languages to promote national consciousness and unity. However, Malaysia seems successful in the language policy. Malaysia uses Malay language as the medium of instruction alongside English language, even at higher education level. Malaysia's curriculum policy takes care of the minority ethnic languages - Chinese, Tamil, and others. Another feature of Malaysian curriculum is the character of integrated approach in many subject areas.

The integrated approach is the major focus in the design of the Integrated Curriculum for Primary School (ICPS) and Integrated Curriculum for Secondary School (ICCS). Several subject areas have been designed in pursuance of an integrated approach which has been well received and successful. The curriculum introduces "integrated living skills" as a separate subject area. Malaysian curriculum offers a list of engineering, technology, and vocational subjects at upper secondary level. This strategy shows that the 
education system highly emphasizes on the production of trained professionals and expert technicians for industrial work.

The national curriculum in Romania is structured on seven curricular areas, which were assigned according to epistemological and psycho-pedagogical criteria. These curricular areas are: language and communication, mathematics and natural sciences, man and society, arts, physical education and sports, technologies, counseling and guidance. The selection of the content area exhibits a symmetry in the curricular practices and promises equity and balance to offer quality education. The curriculum seems more practical and feasible. It doesn't exaggerate educational attainment beyond access. It bases on Piaget's approaches of cognitive behaviorism and constructivism and moves to Dewey's concepts of experience and democracy. It vitalizes the importance of intuition and imagination in educational practices.

\section{RECOMMENDATIONS}

All three curricula (Pakistan, Malaysia, and Romania) have the basic structure of Tyler's rationale. However, each of the curriculum leans towards latest, researched-based approaches and models of curriculum planning, development, and reform. The curricula also incorporate and suggest the latest teaching and learning techniques - mastery learning, creative and critical thinking skills, inquiry and discovery, learning how to learn, cooperative learning, and so on. One of the prominent points in Romanian curriculum is that it connects educational practices with social issues as espoused by reconceptualizes and postmodernists. Romanian curriculum also emphasizes on the reflection of social and cultural values.

\section{REFERENCES}

Apple, M. W. (1979). Ideology and curriculum. London: Routledge \& K. Paul.

Boschee, F., \& Baron, M. A. (1993). Outcome-based education: Developing Programs through Strategic Planning. Lancaster, Pa: Technomic Pub.

Doll, W. E. (1993). A post-modern perspective on curriculum. New York: Teachers College Press.

Egbert, J. \& Sanden, S (2014). Foundations of Education Research: Understanding Theoretical Components. New York: Routledge.

English, F. W. (2010). Deciding what to teach \& test: Developing, aligning, and 
leading the curriculum. Thousand Oaks, Calif: Corwin Press.

Films for the Humanities \& Sciences (Firm), TED Conferences LLC., \& Films Media Group. (2006). TEDTalks: Sir Ken Robinson, Do Schools Kill Creativity? New York, N.Y: Films Media Group.

Freire, P. (2000). Pedagogy of the oppressed. New York: Continuum.

Giroux, H. A. (1981). Ideology, culture \& the process of schooling. Philadelphia: Temple University Press.

Glatthorn, A. A., Boschee, F., \& Whitehead, B. M. (2006). Curriculum leadership: Development and implementation. Thousand Oaks: SAGE Publications.

Greene, M. (1973). Teacher as stranger: Educational philosophy for the modern age. Belmont, Calif: Wadsworth Pub. Co.

Greene, M. (1995). Releasing the imagination: Essays on education, the arts, and social change. San Francisco: Jossey-Bass Publishers.

Grumet, M. R. (1981). Restitution and reconstruction of educational experience: an autobiographical method for curriculum theory. In Gough, Noel. (2004). A vision for transnational curriculum inquiry. Transnational Curriculum Inquiry, 1(1) http://nitinat.library.ubc.ca/ojs/index.php/tci

Henderson, J. (2015). Reconceptualizing curriculum development: Inspiring and informing action. New York: Routledge.

Henson, K. T. (1995). Curriculum planning: Integrating multiculturalism, constructivism, and education reform. Dubuque, IA: McGraw-Hill.

Johnson, T. H., \& Mason, M. C. (2008). No sign until the burst of fire: Understanding the Pakistan-Afghanistan border.

Kanu, Y. (2006). Curriculum as cultural practice: Postcolonial imaginations. Toronto: University of Toronto Press.

Karim, M. F. \& Nawaz, M. (1995). Karez Irrigation in Pakistan. GeoJournal, 37(1), 91-100.

Kelly, A. V. (2004). The curriculum: Theory and practice. London: Sage Publications.

Nayyar, A. H. (2013). A Missed Opportunity: Continuing Flaws in the New Curriculum and Textbooks after Reform. A Report to Jinnah Institute Islamabad.

Ornstein, A. C., \& Hunkins, F. P. (1998). Curriculum: Foundations, principles, and issues. Boston: Allyn and Bacon.

Pennycook, A. (1994). The cultural politics of English as an international language. London: Longman.

Pinar, W. F. (1975). Curriculum theorizing: The reconceptualists. Berkeley, Calif: McCutchan Pub. Corp.

Pinar, W. F. (1995). Understanding curriculum: An introduction to the study of historical and contemporary curriculum discourses. New York: P. Lang.

Pinar, W. (2004). What is curriculum theory? Mahwah, N.J: Lawrence Erlbaum.

Rizvi, F., \& Lingard, B. (2010). Globalizing education policy. London: Routledge. 
Pakistan Journal of Educational Research. Vol 2. Issue 2 (2019) _ Comparative analysis...

Slattery, P. (1995). Curriculum development in the postmodern era. New York: Garland Pub.

Taba, H. (1962). Curriculum development; theory and practice. New York: Harcourt, Brace \& World.

UNESCO (2006). Education for All Report. Retrieved from, http://www.unesco.org/new/en/education/themes/leading-the-internationalagenda /efareport/reports/2006-literacy. 